Vol. 2, No. 1, Desember 2021

\title{
PENDAMPINGAN PENGEMBANGAN KAPASITAS PRODUKSI DENGAN VALUE CHAIN ANAL YSIS PADA UMKM BATIK SEKARNITI YOGYAKARTA
}

\author{
Kholifah Fil Ardhi \\ Politeknik Harapan Bersama \\ kholifahfilardhi@gmail.com \\ Fitri Amaliyah \\ Politeknik Harapan Bersama \\ fitri.amaliyah@poltektegal.ac.id \\ Naila Hanum \\ Politeknik Harapan Bersama \\ nailahanum@poltektegal.ac.id
}

\section{Info Artikel}

Diterima:

16-11-2021

Direvisi:

24-12-2021

Diterbitkan:

24-12-2021

\begin{abstract}
MSME activities (Micro, Small and Medium Enterprises)

are dominated by human labor or labor-intensive, which means that the absorption of labor is very high in the MSME sector. Batik Sekarniti is a small industry engaged in the production of traditional batik. PKM activities carried out online and offline went well and smoothly. The face-to-face meeting aims to conduct a pre-survey of the condition of MSMEs so as to help plan PKM activities. The core of the activity is mentoring and training which is held online using Google Meet media. The participants of the activity were 30 people consisting of two owners and 28 employees of the Batik Sekarniti UMKM located in Temanggal, Wijimulyo, Nanggulan, Kulon Progo, DI. Yogyakarta. The results of the activity show that there is potential for UMKM Batik Sekarniti to increase production capacity, namely in the process of batik writing.

Keywords: SMEs; Value Chain Analysis;

Production Capacity; SMEs Performance
\end{abstract}

DOI: 10.29303 /abdimassangkabira.v2i1.63 


\section{Pendahuluan}

Usaha Mikro Kecil Menengah (UMKM) merupakan salah satu penggerak ekonomi negara Indonesia. Keunikan dan kearifan local Indonesia menjadikan negara ini tumbuh banyak UMKM di kalangan masyarakat mulai dari masyarakat pedesaan hingga masyarakat perkotaan (Anggarini dan Nasution, 2013). Berbasai sektor usaha berdiri mulai dari sektor konsumsi, wisata, seni, pakaian, dan sebagainya. Kegiatan UMKM pun didominasi dengan tenaga manusia atau padat karya yang artinya penyerapan tenaga kerja sangatlah tinggi di sektor UMKM. Sebagai contoh, usaha batik yang masih menghandalkan proses tradisional tentu saja memiliki banyak karyawan yang bekerja pada bagian canthing atau batik tulis. Selain itu, sebagian besar pelaku UMKM menjalani usaha sesuai dengan minat mereka. Artinya, pekerjaan yang dilakukan sesuai dengan minat dan bidangnya tentu saja akan meningkatkan semangat dan etos kerja sehingga menciptakan kinerja yang baik.

Batik Sekarniti merupakan industri kecil yang bergerak dalam bidang produksi batik tradisional. Usaha ini tergolong dalam UMKM yang telah memiliki perizinan lengkap. Adapun produk yang dihasilkan yaitu batik tulis dan cap. Batik tulis merupakan batik yang diproses dengan menggunakan peralatan canthing dalam melekatkan malam (lilin) ke kain. Sedangkan untuk batik cap tidak menggunakan canthing namun menggunakan cap yang terbuat dari bahan tembaga dengan ukuran yang lebar untuk melekatkan malam (lilin) ke kain. Selain memproduksi kain batik, usaha ini juga mengolah kain batik menjadi pakaian jadi. Adapun pakaian jadi yang diproduksi diantaranya yaitu kemeja pria, blues wanita, lukisan batik, sajadah, taplak meja, dan sebagainya. Produk kain dan pakaian jadi ini dijual kepada konsumen langsung (pesanan sedikit) maupun konsumen dengan pesanan yang banyak. Dalam kegiatan sehari-hari, usaha ini menemui berbagai kendala yang menghambat perkembangan usaha. Kendala tersebut meliputi aspek produksi, aspek pemasaran, aspek administrasi, dan sebagainya. Adapun aspek produksi memiliki kendala pada hal sumber daya manusia. Batik tradisional merupakan usaha yang padat karya, artinya proses pengerjaannya membutuhkan banyak sumber daya manusia dan hampir tidak menggunakan mesin sehingga sangat memberdayakan manusia. Ketelitian dan bakat seni menjadi syarat sebagai tenaga kerja yang bekerja di Batik Sekarniti. Tanpa keduanya, calon karyawan tidak bisa lolos untuk bekerja ke tahap selanjutnya. Selain itu, proses produksi batik layaknya industri lain yang mengeluarkan limbah. Limbah ini tentu saja menjadi tanggungjawab bagi setiap pengusaha untuk bisa dilakukan perlakuan (treatment) agar tidak membahayakan linkungan. Namun, pembangunan fasilitas pengolahan limbah memerlukan investasi dana yang cukup besar. Selain aspek produksi, aspek pemasaran juga menjadi hal yang penuh 
tantangan. Perlu adanya pendalaman keunggulan dari Batik Sekarniti yang menjadikan keunikan (uniqueness) agar dapat memenangkan kompetisi pasar. Selain itu, dalam menunjang kegiatan penjualan perlu didukung fasilitas tempat penjualan yang representatif.

Proses produksi menjadi hal yang sangat penting di usaha Batik Sekarniti. Tanpa adanya sistem produksi yang stabil dan handal maka usaha ini tidak bisa memenuhi kebutuhan produk untuk diperdagangkan. Uniknya, UMKM yang menyerap banyak tenaga kerja ini, menghandalkan sumber daya manusianya dalam proses produksi. Proses produksi batik pada usaha ini masih didominasi dengan tangan manusia terutama proses canthing atau batik tulis. Sebagian besar karyawan Batik Sekarniti adalah lulusan Sekolah Menengah Kejuruan (SMK) oleh karenanya mereka belum dibekali keterampilan dan pengamalan yang cukup dengan volume produksi Batik Sekarniti yang tinggi. Selain itu, banyak karyawan yang mengundurkan diri sebagai karyawan dan berpindah kerja ke pabrik (industry yang lebih besar). Hal ini tentu saja menjadikan posisi persaingan tenaga kerja Batik Sekarniti yang rendah dibanding dengan industry yang lebih besar dan memiliki remunerasi karyawan yang lebih bagus. Tidak hanya itu, proses yang tradisional atau proses yang dilakukan tanpa keterlibatan mesin otomatis menjadikan usaha ini harus bisa menjaga rantai produksi yang stabil. Sebagai contoh, usaha ini masih menghandalkan sinar matahari untuk mengeringkan kain batik yang basar. Jika kondisi musim penghujan datang maka proses pengeringan menjadi terhambat.

Kontribusi UMKM terhadap Produk Domestik Bruto (PDB) yaitu meningkat $7,1 \%$. Kotribusi penyerapan tenaga kerja pun mencapai $10,7 \%$ atau sekitar 12 juta total tenaga kerja. Dengan kinerja demikian maka UMKM memiliki potensi besar dalam membangun pundi-pundi perekonomian negara. Penyerapan tenaga kerja yang tinggi ini menjadikan ekonomi di sekitar wilayah UMKM menjadi ikut berkembang. Mobilitas tenaga kerja menjadikan ekonomi sekitar menjadi hidup. Hal ini dapat dilihat dari pola konsumsi makanan karyawan, bahan bakar minya yang digunakan, hingga kebutuhan sehari-hari karyawan.

Daerah Istimewa Yogyakarta merupakan salah satu provinsi di Indonesia yang memiliki pelaku usaha UMKM sangat banyak. Sektor UMKM yang berada di wilayah tersebut pun juga beraneka ragam mulai dari sektor pariwisata, kuliner, hingga kesenian. Keanekaragaman inilah menjadikan provinsi Daerah Istimewa Yogyakarta menjadi salah satu sentra UMKM. Ada berbagai program yang diinisiasi oleh pemerintah daerah untuk mendukung dan mendorong kinerja UMKM. Salah satunya adalah program pemberdayaan UMKM dari segi finansial dan non-finansial. Aspek finansial meliputi aspek 
permodalan, pinjaman dengan bunga ringan, hingga dana hibah. Sedangkan untuk aspek non-finansial meliputi pengembangan kapasitas produksi, manajemen sumber daya manusia, hingga pengolahan limbah. Adapun tujuan pengabdian masyarakat yaitu untuk memberikan wawasan tentang peningkatan kapasitas produksi dengan value chain analysis kepada mitra pengabdian yaitu Batik Sekarniti.

\section{Metode}

Khalayak sasaran kegiatan pendampingan pengembangan kapasitas produksi ini adalah pemilik dan karyawan Batik Sekarniti di Daerah Istimewa Yogyakarta. Kegiatan dilaksanakan secara daring dengan menggunakan vidio conference Google Meet. Kegiatan secara daring dilakukan karena situasi pandemic covid-19 yang mengharuskan segala jenis kegiatan lapangan diganti dengan kegiatan secara daring. Namun, beberapa kegiatan dilakukan secara luring seperti kunjungan ke mitra pengabdi. Adapun jumlah peserta yang mengikuti pendampingan yaitu sebanyak 30 peserta. Instruktur dan narasumber dalam kegiatan ini adalah dosen Program Studi DIII Akuntansi Politeknik Harapan Bersama yang telah menguasai bidang manajemen produksi.

Untuk memecahkan masalah yang sudah diidentifikasi dan dirumuskan pada bagian sebelumnya maka pemecahan masalah yang dilakukan yaitu pendampingan dilakukan dengan pendekatan individual dan klasikal. Pendekatan klasikal dilakukan pada saat pemberian teori tentang pengembangan media pembelajaran yang benar dan pendekatan individual dilakukan pada saat latihan membuat media pembelajaran yang memenuhi standar sertifikasi. Adapaun metode yang digunakan sebagai berikut;

1. Ceramah bervariasi

Metode ini dipilih untuk menyampaikan konsep-konsep yang penting untuk dimengerti dan dikuasai oleh peserta pelatihan. Penggunaan metode ini dengan pertimbangan bahwa metode ceramah yang dikombinasikan dengan gambar-gambar, animasi dan display dapat memberikan materi yang relative banyak secara padat, cepat dan mudah. Materi yang diberikan meliputi: konsep media pembelajaran, macam media, kelebihan dan kekurangan media, dan langkah-langkah pengembangan media pembelajaran berbasis komputer.

2. Demonstrasi

Metode ini dipilih untuk menunjukkan suatu proses kerja yaitu tahap-tahap pengembangan media pembelajaran berbasis komputer. Demonstrasi dilakukan oleh instruktur di hadapan peserta yang masing-masing mengoperasikan satu komputer sehingga peserta dapat mengamati secara 
3. Latihan

langsung metode dan teknik pengembangan media pembelajaran yang layak dipakai dalam serifikasi guru.

Metode ini digunakan untuk memberikan tugas kepada peserta pendampingan untuk mempraktikkan pembuatan media yang memenuhi persyaratan program sertifikasi guru.

Adapun langkah-langkah kegiatan yang dilakukan adalah pendampingan secara intensif dengan tahapan sebagai berikut:

1. Ceramah tentang pengantar konsep Value Chain Analysis

2. Ceramah tentang tujuan dan manfaat Value Chain Analysis

3. Ceramah tentang contoh implemetnasi Value Chain Analysis di perusahaan

4. Demonstrasi tentang langkah-langkah implementasi Value Chain Analysis

5. Pendampingan persiapan implementasi Value Chain Analysis di UMKM

6. Evaluasi hasil pendampingan yang telah dilakukan

Berdasarkan evaluasi pelaksanaan dan hasil kegiatan dapat diidentifikasi faktor pendukung dan penghambat dalam melaksanakan program pengabdian pada masyarakat ini. Secara garis besar faktor pendukung dan penghambat tersebut adalah sebagai berikut:

Faktor Pendukung:

a. Tersedian tenaga ahli yang telah memahami konsep pengembangan kapasitas produksi di Program Studi DIII-Akuntansi Politeknik Harapan Bersama

b. Antusiasme dari pemilik dan karyawan UMKM yang cukup tinggi terhadap pendampingan dan pelatihan pengembangan kapasitas produksi karena ternyata UMKM telah memiliki fasilitas produksi yang memadahi namun kurang memiliki keterampilan untuk meningkatkan kapasitas produksi mereka.

c. Dukungan dari pemilik UMKM Batik Sekarniti untuk mengimplementasikan Value Chain Analysis bahkan pemilik juga membantu dalam mengarahkan karyawan mereka selama kegiatan berlangsung

d. Adanya hubungan yang baik antara tim pengadi dan mitra pengabdi sehingga proses komunikasi dari awal kegiatan hingga selesai berjalan dengan baik

Faktor Penghambat:

a. Banyak karyawan yang lulusan SMA dan SMK sehingga kurang memiliki pengetahuan seputar manajemen produksi oleh karenanya tim pengabdi perlu melakukan pendekatan individu agar mempercepat terserapnya keterampilan yang diberikan.

b. Metode daring menjadikan kurang efektifnya kegiatan diselenggarakan sehingga para peserta pendampingan kurang bisa fokus pada materi yang 
diberikan, namun tim pengabdi mengatasinya dengan cara memberikan materi bahan lepas yang bisa dipelajari secara mandiri oleh karyawan

c. Kegiatan dilakukan saat kapasitas produksi maksimum sehingga jadwal karyawan sangatlah padat oleh karenanya tim pengabdi meminta hari khusus kepada pemilik UMKM agar karyawan bisa fokus dalam mengikuti kegiatan pengabdian ini

Kerangka penyelesaian masalah dalam kegiatan pengabdian masyarakat ini adalah dengan melakukan pelatihan tentang pengembangan kapasitas produksi dengan value chain analysis untuk menambah pengetahuan dalam rangka meningkatkan kapasitas produksi dan kinerja dari UKM (Walters dan Lancaster, 2000).

Realisasi pemecahan masalah yang diharapkan dapat dicapai dengan adanya program pengabdian masyarakat antara UMKM Batik Sekarniti Yogyakarta dengan Prodi DIII Akuntansi Politeknik Harapan Bersama Tegal diantaranya adalah target yang diharapkan dari adanya kegiatan pengabdian masyarakat ini adalah terlaksananya kegiatan pendampingan pengembangan kapasitas produksi dengan value chain analysis. Target yang diharapkan dari adanya kegiatan pengabdian masyarakat ini adalah adanya forum untuk sharing dan konsultasi tentang perkembangan ilmu akuntansi bagi UMKM Batik Sekarniti Yogyakarta maupun Dosen Politeknik Harapan Bersama.

\section{Hasil}

Kegiatan PKM yang dilaksanakan secara daring dan luring berjalan dengan baik dan lancar. Pertemuan tatap muka bertujuan untuk melakukan pra-survey terhadap kondisi UMKM sehingga membantu perencanaan kegiatan PKM. Inti dari kegiatan yaitu pendampingan dan pelatihan yang diselenggarakan secara daring dengan menggunakan media Google Meet. Kegiatan ini dilaksanakan selama satu hari yaitu pada hari Jumat tanggal 20 Agustus 2021 dari pukul 09.00 WIB hingga 12.00 WIB. Peserta kegiatan berjumlah 30 orang yang terdiri dari dua orang pemilik dan 28 karyawan UMKM Batik Sekarniti yang berlokasi di Temanggal, Wijimulyo, Nanggulan, Kulon Progo, DI. Yogyakarta. Pelaksanaan kegiatan PKM ini dilakukan oleh 2 (dua) orang tim pengabdi dengan pokok bahasan yang disampaikan sebagai berikut;

1. Pengantar pengembangan kapasitas produksi dengan Value Chain Analysis

2. Tujuan dan manfaat pengembangan kapasitas produksi melalui Value Chain Analysis

3. Contoh implementasi Value Chain Analysis di perusahaan

4. Langkah-langkah persiapan implementasi Value Chain Analysis

5. Pendampingan persiapan 
Keterbatasan waktu pertemuan mengakibatkan tidak semua materi dapat disampaikan secara rinci. Adapun jadwal kegiatan adalah sebagai berikut:

\begin{tabular}{|l|l|l|}
\hline No & \multicolumn{1}{|c|}{ Agenda } & \multicolumn{1}{c|}{ Keterangan } \\
\hline 1 & $\begin{array}{l}\text { Pra survey melalui Focus Group } \\
\text { Discussion (FGD) dengan pemilik UMKM } \\
\text { Batik Sekarniti Yogyakarta }\end{array}$ & Tim PKM \\
\hline 2 & Penyusunan materi pengampingan & Tim PKM \\
\hline 3 & Permohonan izin pelaksanaan kegiatan & Tim PKM \\
\hline 4 & Kegiatan Pendampingan & Naila Hanum, S.E., M.Acc. \\
\hline 4.1 & Pembukaan oleh MC & Kholifah Fil Ardhi, S.E., M.Acc. \\
\hline 4.2 & Sambutan dari Ketua Tim Pengamdian & Sarwiyani \\
\hline 4.3 & Sambutan pemilik UMKM Batik Sekarniti & Tim PKM \\
\hline 4.4 & Penyampaian materi & Tim PKM \\
\hline 4.5 & Diskusi dan Tanya Jawab & Naila Hanum, S.E., M.Acc. \\
\hline 4.6 & Penutupan & \multicolumn{2}{|l}{} \\
\hline
\end{tabular}

Kegiatan pengabdian kepada masyarakat telah terlaksana sesuai dengan jadwal yang telah ditentukan. Pelaksanaan kegiatan telah dilakukan selama satu semester terhitung dari tahap perencanaan sampai tahap evaluasi. Kegiatan ini telah terlaksana sesuai dengan rencana yang telah ditetapkan.

Kegiatan ini dihadiri oleh 13 karyawan dan 1 pemilik UMKM Batik Sekarniti Yogyakarta serta 3 dosen DIII Akuntansi Politeknik Harapan Bersama. Secara prinsip, UMKM memiliki permasalahan dalam hal kapasitas produksi yang tidak bisa dikembangkan. Berbagai keterbatasan dimiliki oleh UMKM mulai dari yang bersifat finansial hingga non-finansial yang harus diselesaikan. Berdasarkan hasil Forum Group Discussion (FGD) bahwa UMKM menginginkan agar kapasitas produksi mereka dapat ditingkatkan. Hal ini dikarenakan UMKM harus bisa melayani konsumen dengan jumlah penjualan yang tinggi. Selain itu, kapasitas produksi juga merupakan salah satu kunci dari daya saing UMKM di pasar. Dengan terpenuhinya kebutuhan pelanggan maka UMKM dapat dikatakan unggul.

\section{Diskusi}

Hasil diskusi menghasilkan bahwa proses produksi UMKM Batik Sekarniti dilakukan dengan lima tahapan proses produksi dasar. Berikut adalah gambar yang menunjukkan proses produksi pada UMKM Batik Sekarniti; 



\section{Gambar 1 Proses Produksi UMKM Batik Sekarniti}

Pada gambar di atas maka dapat dianalis bahwa terdapat lima tahapan proses produksi. Hasil diskusi digunakan untuk mengetahui apakah dalam proses produksi masih terjadi kekurangan kapasitas. Ditemukan bahwa proses batik (chanting) yang masih dilakukan oleh tenaga manusia masih mengalami kendala. Kendala tersebut dikarenakan susahnya mencari tenaga kerja yang memiliki keahlian dalam membatik. Oleh karenanya, produk batik tulis kini biayanya cukup mahal. Adapaun pemecahan masalah dari kondisi ini yaitu memberikan saran kepada UMKM untuk menjadikan produk batik tulis menjadi produk premium agar dapat menutupi biaya produksi dan mampu bersaing di pasar.

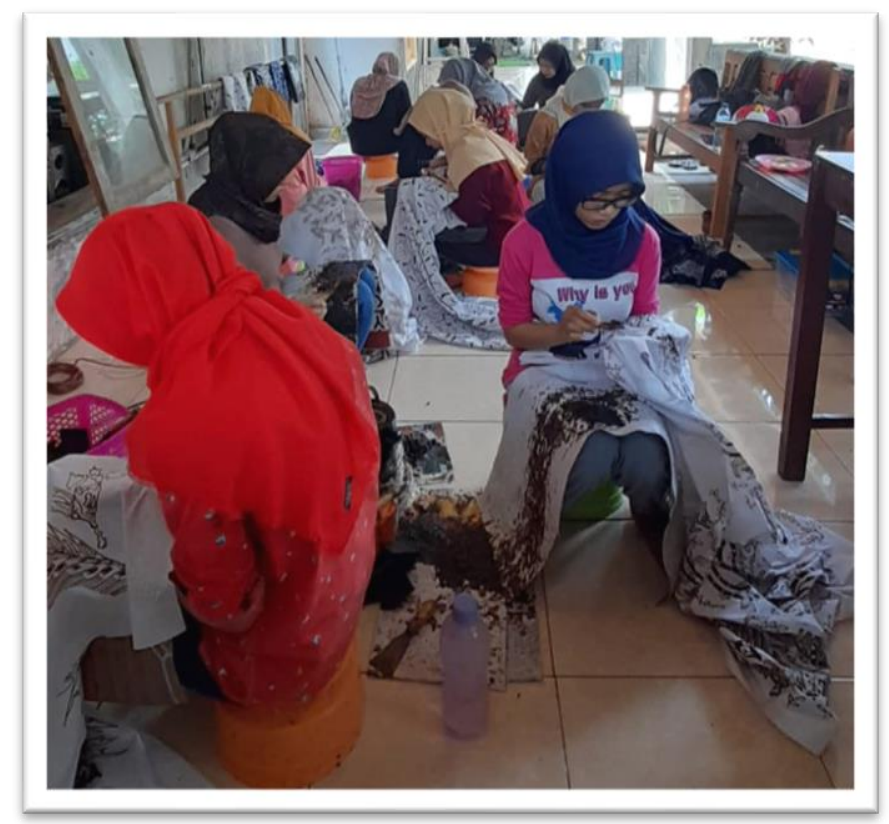

Gambar 2 Proses Chanting 
Gambar di atas menunjukkan proses chanting yang dilakukan oleh UMKM Batik Sekarniti Yogyakarta. Tenaga kerja merupakan faktor utama suatu bisnis. UMKM Batik Sekarniti sangat membutuhkan adanya tenaga kerja yang mampu membatik. Oleh karenanya, tim pengabdi memberikan saran kepada UMKM untuk bisa melakukan pelatihan dan pendidikan secara singkat kepada tenaga kerja baru agar mereka siap untuk bekerja dan menjadi mampu untuk membatik.

Proses chanting merupakan proses yang digunakan untuk memproduksi batik tulis. Jumlah yang diproduksi pun memang terbatas tidak seperti batik cap. Oleh karenanya, UMKM harus menjadikan karakteristik dari batik tulis sebagai keunggulan dari produk tersebut. Jumlah produksi yang sedikit menjadikan baju yang diproduksi menjadi terbatas. Ini merupakan potensi yang dapat dimanfaatkan oleh UMKM untuk mentargetkan kelas atas yang menginginkan produk yang berkualitas dan unik.

Kegiatan pengabidan pada masyarakat ini ditutup dengan laporan dan luaran yang ditargetkan oleh tim pengabdi. Adapun luaran dari hasil pendampingan ini akan dipublikasikan pada jurnal Dikemas Politeknik Negeri Madiun; buku ajar mata kuliah manajemen produksi; dan publikasi media.

\section{Kesimpulan}

Berdasarkan hasil kegiatan yang telah dilaksanakan dapat disimpulkan bahwa:

a. Kegiatan pengabdian pada masyarakat telah dilaksanakan sesuai dengan rencana.

b. Hasil kegiatan menunjukkan bahwa terdapat potensi bagi UMKM Batik Sekarniti untuk meningkatkan kapasitas produksi yaitu pada proses batik tulis.

c. Dibutuhkan pendampingan lebih lanjut untuk strategi penjualan produk UMKM Batik Sekarniti.

Berdasarkan kegiatan pengabdian pada masyarakat yang telah dilaksanakan, berikut adalah saran yang dapat diberikan;

a. Untuk pengabdi selanjutnya agar bisa melakukan kegiatan yang serupa yaitu pendampingan peningkatan kapasitas produksi dengan value chain analysis namun agar UMKM Batik Sekarniti lebih mendalami bagaimana cara meningkatkan kapasitas produksi dengan inovasi.

b. Perlu adanya lembar evaluasi yang diedarkan kepada UMKM untuk mengetahui feedback kegiatan pengabdian ini.

c. Perlu adanya keterlibatan pemerintah lokal seperti dinas koperasi agar dapat mendalami permasalahan UMKM secara umum. 


\section{Daftar Referensi}

Anggraini, Dewi, and Syahrir Hakim Nasution. "Peranan kredit usaha rakyat (KUR) bagi pengembangan UMKM di Kota Medan (studi kasus Bank BRI)." Ekonomi dan Keuangan 1.3 (2013).

Jurevicius, Ovidijus. 2013. Value Chain Analysis. Strategic Managegment Insight. https://strategicmanagementinsight.com/tools/value-chainanalysis.html

Walters, David, and Geoff Lancaster. "Implementing value strategy through the value chain." Management Decision (2000). 